\title{
A Theoretical Study of the Cooling of a Disk by an Impinging Jet of Water
}

Shoji TANiguchi, Atsushi Kikuchi, and Teiriki TAdaki

Synopsis :

Theoretical studies were made to discuss the mechanism of unsteady heat transfer in the system used in the previous experiments, in which a disk of mild steel is cooled at $373 \mathrm{~K}$ by an impinging jet of water.

Four models were discussed concerning the convective heat transfer in the liquid, those of which are unsteady-state model (A), quasi-steady-state model (B), steady-state and constant heat flux model (C) or constant wall temperature model (D).

First, distributions of temperatures in the fluid and solid, local heat fluxes and local Nusselt numbers at the fluid-solid interface were computed by model $A$ and $B$. It was found that the results of model A were consistent with those of model B except initial stage of cooling, and that the calculated temperatures in the solid were consistent with observed ones.

Secondly, distributions of temperatures in the solid were computed by model C and D. Model C showed a suitable agreement with calculated ones by model A and B, and observed ones, while model $\mathrm{D}$ showed lower temperature than observed ones. From these results, it seemed sufficient to use model $\mathrm{C}$ for estimation of temperature in the solid.

\section{1. 緒言}

著者らは噴流水による固体円板の冷却に関する研究の 一環として，これまで噴流水一固体円板間の対流伝熱と 固体内熱伝導の二つの過程からなる非定常熱移動現象を 実験的に検討し1)，また噴流水一固体円板間の定常対 流 伝熱を理論的，実験的に検討した22.

本報では前報》の条件下の熱移動現象を理論的に検討 することを目的とした。

\section{2. 伝熱モデルおよび計算方法}

Fig. 1 亿前報》で用いた実験系の概略を示した，真 空容器内で所定温度 $\theta_{\mathbf{0}}(\approx 373 \mathrm{~K})$ に保持した固体円板 の表面に円柱ノズルより常温 $\theta_{\mathrm{w}}$ の水を噴射して固体 円板を冷却し，その場合の固体内温度の経時変化を測定 した.

その実験条件は以下のと拈りである：

固体円板の半径 $r_{0}=0.05,0.075 \mathrm{~m}$; 固体円板の厚さ $z_{0}=(1.5 \sim 5.0) \times 10^{-2} \mathrm{~m} ; \quad$ ノズル下端から固体円板表 面までの距離 $H=(5 \sim 15) \times 10^{-2} \mathrm{~m}$; ノズル内待 $d=$ $(0.4 \sim 1.3) \times 10^{-2} \mathrm{~m} ;$ ノズル内の水の平均速度 $v_{0}=2.7$ $\sim 15.9 \mathrm{~m} / \mathrm{s}$.

以上の条件下の熱移動現象を理論的に考察するにあた り，固体円板上の液膜内の流孔は前報2) と同様層流境界 層内の定常流で，また境界層内の熱移動は半径方向の熱 伝導を無視した対流伝熱で近似しらると仮定した。 一方 固体内熱移動も前報1) と同様, 非定常 2 次元 $(r, z)$ 熱

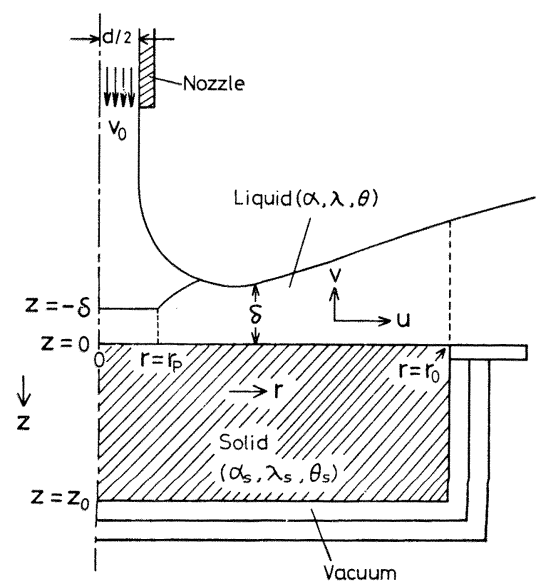

Fig. 1. Experimental system for heat transfer1).

昭和 53 年 10 月本会購演大会にて発装 睢和 57 年 2 月 1 月受付 (Received Feb. 1, 1982)

* 東北大学工学榊 T. 博 (Faculty of Engineering, Tohoku University, Aza-Aoba Aramaki Sendai 980) 
伀導とみなした。 また流体拈よび固体の物性值も前報1)

2) と同様一定とみなした。

本報では，非定常対流伝熱拉よび前報1)で用いた定常 下の等熱流束モデルなどを検討するために，以下に示す ような種々の対流伝熱モデルを用いた。

\section{1 伝熱モデル}

（1）非定常対流伝熱モデル（モデルA）

本報では前述のごとく，流体の流れを定常としたの で，流体側の非定常熱移動を考慮して系内熱移動を考察 するには流体および固体側の初期状態をモデル化する必 要がある. 本報では, 流体および固体側の初期状態とし てそれぞれ $\theta_{\mathrm{w}}$ および $\theta_{\mathbf{0}}$ の仮想的な状態を考えたり。こ れを非定常対流伝熱モデル（モデルA） と呼ぶ.

このモデルによる系内熱移動の基礎式，初期条件およ び境界条件は以下の諸式で与党られる.

固体側

$$
\begin{aligned}
& \frac{\partial \theta_{\mathrm{s}}}{\partial t}=\alpha_{\mathrm{S}}\left[\begin{array}{cc}
\frac{1}{r} & \partial \\
\partial r
\end{array}\left(\begin{array}{cc}
r & \partial \theta_{\mathrm{s}} \\
\partial r
\end{array}\right)+\begin{array}{c}
\partial^{2} \theta_{\mathrm{s}} \\
\partial z^{2}
\end{array}\right] \\
& t=0: \theta_{\mathrm{s}}=\theta_{0} \\
& r=r_{0}, \quad z=0 \sim z_{0}: \partial \theta_{\mathrm{s}} / \partial r=0 \\
& r=0, \quad z-0 \sim z_{0}: \partial \theta_{\mathrm{s}} / \partial r=0 \\
& z=z_{0}, \quad r=0 \sim r_{0}: \partial \theta_{\mathrm{s}} / \partial z=0
\end{aligned}
$$

流体-円板間界面

$$
\begin{aligned}
& z=0, \quad r=0 \sim r_{0} \\
& \lambda \partial \theta / \partial z=\lambda_{\mathrm{s}} \partial \theta_{\mathrm{s}} / \partial z, \theta=\theta_{\mathrm{s}} .
\end{aligned}
$$

流体側

$$
\begin{aligned}
& \frac{\partial \theta}{\partial t}+u \frac{\partial \theta}{\partial r}+v \frac{\partial \theta}{\partial z}=\alpha \begin{array}{l}
\partial^{2} \theta \\
\partial z^{2}
\end{array} \\
& t=0: \theta=\theta_{\mathrm{w}} \\
& z=-\delta, \quad r=0 \sim r_{\mathrm{p}}: \theta=0_{\mathrm{w}} \\
& z=-\delta, \quad r=r_{\mathrm{p}} \sim r_{0}: \partial \theta / \partial z=0 \\
& r=0, \quad z=-\delta \sim 0: \partial \theta / \partial r=0
\end{aligned}
$$

以上の諸式をつぎのように無次元化した。

$$
\begin{aligned}
& \frac{\partial T_{\mathrm{S}}}{\partial \tau}=\frac{1}{R} \frac{\partial}{\partial R}\left(\begin{array}{c}
\partial T_{\mathrm{s}} \\
\partial R
\end{array}\right)+\frac{\partial^{2} T_{\mathrm{s}}}{\partial z^{2}} \\
& \tau=0: T_{\mathrm{S}}=1 \\
& R=R_{0}, \quad Z=0 \sim Z_{0}: \partial T_{\mathrm{s}} / \partial R=0 \\
& R=0, \quad Z=0 \sim Z_{\mathbf{0}}: \partial T_{\mathrm{s}} / \partial R=0 \\
& Z=Z_{0}, \quad R=0 \sim R_{0}: \partial T_{\mathrm{s}} / \partial Z=0 \\
& Z=0, \quad \eta=0, \quad R=0 \sim R_{0} \text { : } \\
& \partial T / \partial \eta=\left(J / \lambda_{\mathrm{R}}\right) \partial T_{\mathrm{s}} / \partial Z, \quad T=T_{\mathrm{s}} \\
& \frac{\partial T}{\partial \tau}+P e \cdot \alpha_{\mathrm{R}}\left[\begin{array}{l}
\partial T \\
\partial R
\end{array}+\frac{1}{J}\left(V-\eta U \frac{d \mathcal{J}}{d R}\right) \frac{\partial T}{\partial \eta}\right] \\
& =\begin{array}{ll}
\alpha_{\mathrm{R}} & \partial^{2} T \\
J^{2} & \partial \eta^{2}
\end{array}
\end{aligned}
$$

+ 時間 $t<0$ で固体および流体側は温度 $\theta_{\mathrm{w}}$ に保たれており, $t=0$ で急 に固体側の温度を $\theta_{0}$ に変化させたことに相当する

$$
\begin{aligned}
& \tau=0: T=0 \\
& \eta=-1, \quad R=0 \sim R_{\mathrm{p}}: T=0 \\
& \eta=-1, \quad R=R_{\mathrm{p}} \sim R_{0}: \partial T / \partial \eta=0 \\
& R=0, \quad \eta=-1 \sim 0: \partial T / \partial R=0
\end{aligned}
$$

（2）擬定常対流伝熱モデル（モデルB）

固体円板の冷却にともない，流体の温度も時間で変化 するが，任意の時間において対流伝熱過程が定常である とする仮想的な状態をつぎに考えた。 これを擬定常対流 伝熱モデル（モデルB）と呼ぶ.

このモデルでは Eq. (1)〜(4)のほかに, Eq. (15),

Eq. (7) 拈よび Eq. (16) が用いられる.

$$
\begin{gathered}
u \begin{array}{c}
\partial \theta \\
\partial r
\end{array}+v \frac{\partial \theta}{\partial z}=\alpha \begin{array}{l}
\partial^{2} \theta \\
\partial z^{2}
\end{array} \\
t=0: \theta=f(r, z) \cdots \cdots \cdots \cdots
\end{gathered}
$$

Eq. (16) の初期温度分布 $f(r, z)$ は Eq. (15) を Eq. (7) 拉よび $f(r, 0)=\theta_{0}$ の条件で解いた解（数值 解）を用いた。

このモデルの諸式をモデル A と同様無次元化した（つ ぎに示すモデル C, D の場合も同様である).

（3）等熱流束モデル（モデルG）および等温壁モデ ル (モデルD)

等熱流束モデル（モデルG）は Eq. (17) の対流伝熱 係数 $h_{\mathrm{r}}$ として, 界面における熱流束が一定の場合の定 常対流伝熱係数を仮定するもので，これは前報12) の結 果から類推した.

$$
z=0, \quad r=0 \sim r_{0}: \lambda_{\mathrm{s}} \frac{\partial \theta_{\mathrm{S}}}{\partial z}=h_{\mathrm{r}}\left(\theta_{\mathrm{s}}-\theta_{\mathrm{w}}\right)
$$

また比較のために，前報2）之同様，等温壁モデル（モ デルD) (Eq. (17) の $h_{\mathrm{r}}$ として界面温度一定の場合の 定常対流伀熱係数を仮定するモデル）についても計算を 行つた.

これらのモデルでは Eq. (1)〜 (3) および Eq.(17) が用いられる。

なお，Eq. (17) の $h_{\mathrm{r}}$ は流体側の定常温度分布の解 (Eq. (15), Eq. (7), Eq. (18)) と Eq. (19) で求め られるので2)， $h_{\mathrm{r}}$ は固体側の条件には無関係に定まる. したがつて，これらのモデルでは流体一円板間界面にお ける熱の連続条件 (Eq.（4)）は一般には成立しない.

$$
\begin{aligned}
& z=0, r=0 \sim r_{0}: \\
& \lambda \cdot \partial \theta / \partial z=\text { const. (Model } \mathrm{C}) \\
& \text { or } \\
& \theta=\text { const. (Model D) } \\
& \text { C) } \\
& z=0, \quad r=0 \sim r_{0}: \lambda \cdot \partial \theta / \partial z=h_{\mathrm{r}}\left(\theta-\theta_{\mathrm{w}}\right)
\end{aligned}
$$




\section{$2 \cdot 2$ 計算方法}

いずれのモデルの場合も固体側の温度の数值解は前報 1) 之同様, explicit 法で求めた。 流体側の温度の数值解 はモデルAの場合は UDS-ADI3)法により，モデルBの 場合は前報 ${ }^{2)}$ と同様, UDS-SOR 法により求めた。流体 の速度分布としては前報2)で得た近似解や2を用いた。

また，モデル A，B の場合について, Eq. (20)-(a) 抒 よび Eq. (21)-（a）でそれぞれ定義した無次元局所伝 熱速度Qおよよ゙局所ヌッセルト数 $N u$ も求めた.

$$
\begin{aligned}
& Q \equiv \frac{-\left.q_{\mathrm{r}}\right|_{\mathrm{z}=0}}{\left(\lambda / r_{\mathrm{s}}\right)\left(\theta_{0}-\theta_{\mathrm{w}}\right)} \\
& -\left.q_{\mathrm{r}}\right|_{\mathrm{z}=0}=\left.\lambda \frac{\partial \theta}{\partial z}\right|_{\mathrm{z}=0} \\
& N u \equiv \frac{h_{\mathrm{r}} r_{\mathrm{s}}}{\lambda} \\
& -\left.q_{\mathrm{r}}\right|_{\mathrm{z}=0} \equiv h_{\mathrm{r}}\left(\theta-\theta_{\mathrm{w}}\right)
\end{aligned}
$$

Eq. (20)-(b) における $\left.\lambda(\partial \theta / \partial z)\right|_{z=0}$ は $\theta$ をるの 2 次式で近似して求めた。

格子間隔などの条件は以下のとおりである： モデルA

$$
\begin{aligned}
& \Delta R=0.625(R=0 \sim 7.5), \quad 1.25\left(R=7.5 \sim R_{0}\right) ; \\
& \Delta \eta=0.05 ; \quad J Z=0.5 ; \\
& \left.J \tau=10^{-4}(\tau=0 \sim 0.1), \quad J \tau_{\mathrm{k}}-1.002\right\lrcorner \tau_{\mathrm{k}-1} \\
& \left.\left(\Delta \tau_{1}-10^{-4}, \tau-0.1 \sim 5\right), \quad\right\lrcorner \tau=0.01(\tau=5 \sim 320) .
\end{aligned}
$$

$\Delta \tau=0.01$ ，その他はモデル $\mathrm{A}$ と同様である. モデル $\mathrm{C}$

$$
\Delta \tau=0.04(d=0.4,0.8), 0.08(d=1.3) \text {; }
$$$$
\Delta Z=0.5(d=0.4,0.8), 0.154(d=1.3) \text {; }
$$$$
J R=\left(\begin{array}{l}
0.625(R=0 \sim 7.5, \quad d=0.4,0.8) \\
1.25\left(R=7.5 \sim R_{0}, \quad d=0.4,0.8\right) \\
0.3(R=0 \sim 7.5, \quad d=1.3) \\
0.45\left(R=7.5 \sim R_{0}, \quad d=1.3\right)
\end{array}\right.
$$

モデルD

$\Delta \tau=0.04$ ，その他はモデル $\mathrm{G}$ と同様である. なお，計算には東北大学大型計算機センタ ACOS リーズ $77 \mathrm{NEAC} \mathrm{システム} 900$ を用いた.

\section{3. 計算結果および考察}

まず，R $e_{\mathrm{S}}=11000, R_{0}=37.5, Z_{0}=15, P_{r}=8.1$ の 場合について, 温度分布, 局所伝熱速度および局所伝熱 係数の計算值を示し，ついで固体内温度の経時变化に関 する前報1)の実験結果と本報の計算結果とを比較する.

\section{$3 \cdot 1$ モデルAおよびモデル $\mathrm{B}$ の場合}

（1）流体内扰よび国体内の温度分布

†2固体円板表面の液膜の流れ劳風流境界㐿流れと仮定し，境界屋方程

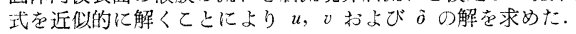

冷却時間 ${ }^{3} \tau=0.1 ， 1 ， 10,100$ に打计る系内温度分 布の計算值を Fig. 2 に示した.

まず，モデルA（非定常対流伝熱モデル）の結果につ いてみてみる.

Fig. 2-(a) より， $\tau=0.1$ の時間では固体は温度 $T$ $=0$ の噴流水によつては注とんど冷却されて拈らず，流 体-固体間の界面近傍でも固体の温度は初期温度 $\left(T_{\mathrm{S}}=\right.$ 1) に近い。しかし，固体円板上の流体の温度は初期温 度 $(T=0)$ とはことなり, 界面で $T=1$ に近く, 液 膜上部にいくにつれて $T \rightarrow 0$ となる温度分布となつて

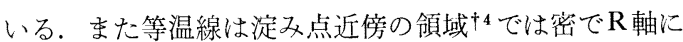
平行であるが，Rが大になると蹯になるとともに右上が りになつている。しかし，さらにRが大になると，その 等温線は逆に右下がりになつている。この等温線が右上 がりから右下がりに移行する $R$ の位置は液膜上部では約 30 に近いが，液膜下部になるにつれて 30 より小さく なる傾向がある。

時間が経過して $\tau=1$ になると（Fig. 2-(b))，界面 近傍 $(Z \approx 0)$ の固体の温度が $R=0$ の方から低下するの がみとめられるようになる。しかし，固体下部の温度は まだ初期温度 $\left(T_{s}=1\right)$ となつている. 一方，流体側で はとの等温線は $\tau=0.1$ の場合とことなり， $R=R_{0}$ の近 傍でも右上がりになつている.

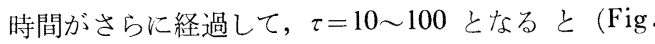
2-(c), (d)), 界面温度はもちろん, 固体下部の温度 b低下してくる.

この固体内の温度は $R=0$ 近傍の領域では $R$ によつて あまり変化していないが，その領域の外では $R$ で変化し ているのがみとめられる。一方, 流体側の温度は固体の 温度の低下とともに全体的に低下してくるが，その等温 線の傾向は $\tau=1$ の場合のそれと類似である.

つぎに，モデルBの計算結果についてみてみると，固 体内の温度分布の計算值はいずれの時間においてもモデ ルAのそれと同じである (Fig. 2(a)〜 (d)). 流体側 の温度分布の傾向はいずれの時間のときも類似で, $R=$ $R_{0}$ の近傍で等温線は右上がりとなつている. また $\tau=$ 0.1 でRの大きいところを除けば温度分布の計算值はモ デルAのそれと同一である (Fig. 2(a)〜 (d)).

(2) 局所伝熱速度

温度分布の計算值より， Eq. (20) で求めた局所伝熱 速度 $Q$ と半径 $R$ との関係を時間 てをバラメータとして

†3 $\tau=0.1 \sim 100$ の無次元時問は $300 \mathrm{~K}$, 杴鋼の場介， $t=0.03 \sim 30 \mathrm{~s} て$ ある

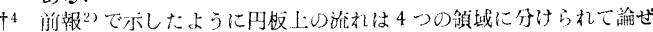
られている。本計算条件の場介, 領域 $\mathrm{I}$ (淀み点近傍の颃域)は $R$ $=0 \sim 2$, 領域II $R=2 \sim 8.32$, 領域 $R=8.32 \sim R_{\mathrm{j}}$ で, またこの 条件下の実驗2)では $R_{0}<R_{\mathrm{j}}$ であるので, 領域IV $\left(R<R_{\mathrm{j}}\right)$ はない 

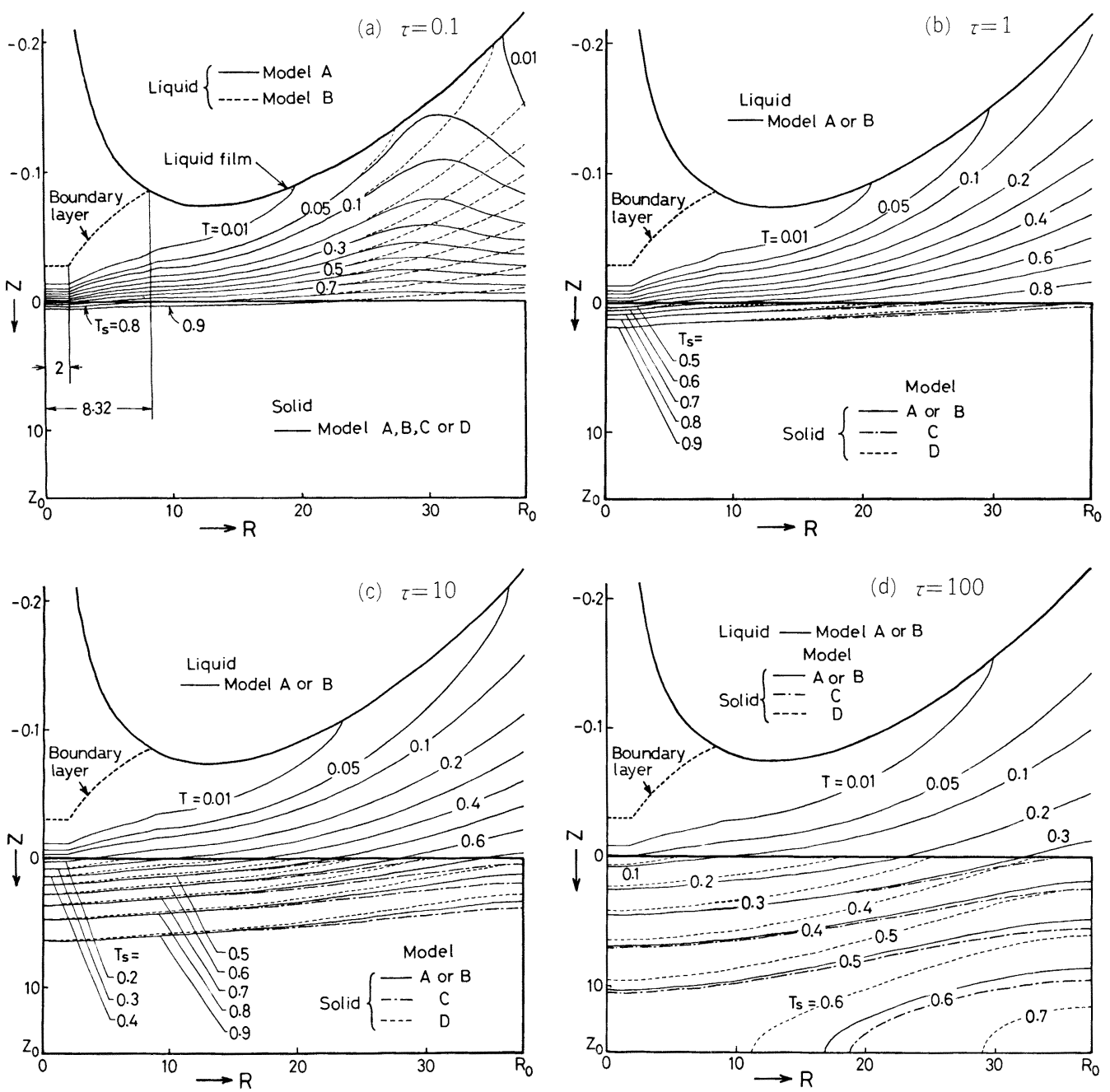

Fig. 2. Temperature profiles $\left(R e_{\mathrm{S}}=11000, \operatorname{Pr}=8.1, R_{0}=37.5, Z_{0}=15\right)$.

Fig. 3 に示した.

まず， $\tau=0.01$ の場合をみると， $R<5$ ではモデル $\mathrm{A}, \mathrm{B}$ のQに差異がなく, そのQは $R=0 \sim 2$ (領域 I : 淀夕点近傍の領域）で注ぼ一定の高い值を示し， $R=2$ ～ 5 では $R$ とともにQは減少している. しかし， $R>5$ ではモデル $\mathrm{B} の Q は R$ ともに減少しているのに対し，

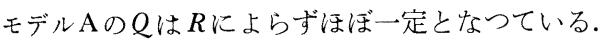

$\tau=0.02$ および 0.05 の場合， $R$ の大きい領域におけ

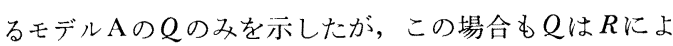
らずほぼ一定となつている，またての経過で，Qの低下 も認められる。

$\tau=0.1$ になると, 二つのモデルの $Q$ が一致する領域 は $R=R_{0}$ 近傍まで広がつており, この領域のQは $\tau=$
0.01 の場合より小さくなつている. $R=R_{0}$ の近傍でモ デル AのQがRとともに大になつているが,これは Fig. 2-(a)に拈いて等温線が右下がりになつていることに対 応する.

$\tau \geq 1$ になると, 両モデルの $Q$ に差異がなくなり, $\tau$ の経過とともにQは全体的に低下するが，その低下の割 合は $R$ が小さいところで著しい，また， $R=R_{0}$ 近傍の 領域を除けばQは $R$ に浪湆無関係に一定となる傾向が認 められる.

(3) 局所伝熱係数

本報のモデル A， B の対流伝熱と前報2)の等熱流束 および 等温壁条件下の対流伝熱とを比較するために, Eq. (21)-(b) で定義した局所伝熱係数 $h_{\mathrm{r}}$ の無次元数 


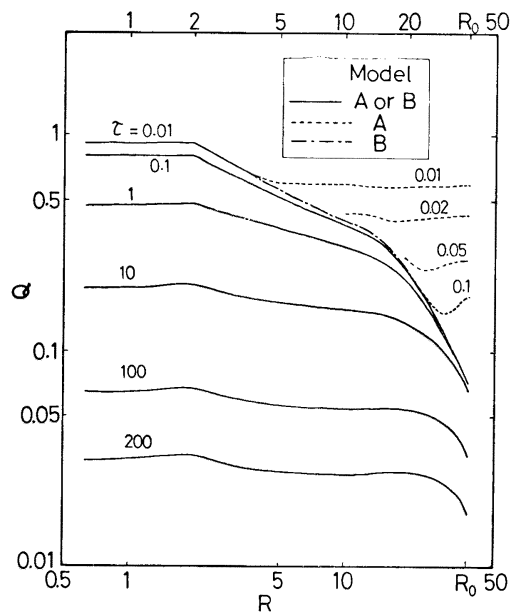

Fig. 3. Values of $Q$ as a function of $R$ at different $\tau\left(R e_{\mathrm{S}}=11000, \operatorname{Pr}=8.1, \quad R_{0}=37.5, Z_{0}\right.$ $=15$ ).

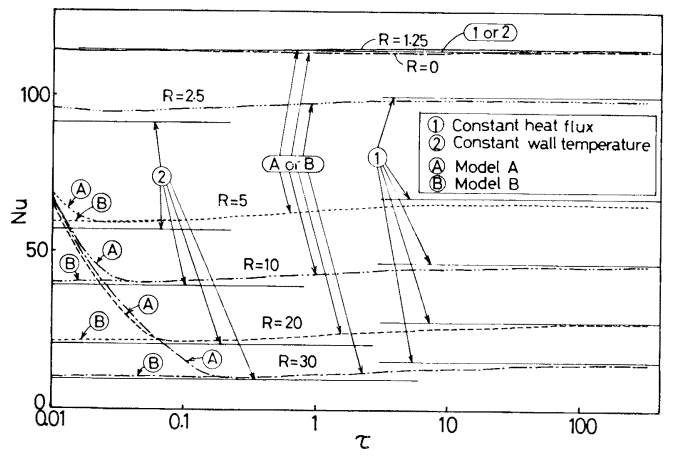

Fig. 4. Values of $N u$ as a function of $\tau$ at different $R\left(R e_{\mathrm{S}}=11000, \operatorname{Pr}=8.1, \quad R_{0}=37.5, Z_{0}=\right.$ 15).

である局所ヌッセルト数 $N u$ (Eq. (21)-(a)) を求め た. Fig. 4 に時間 $\tau=0.01$ 以降の $N u$ と $\tau$ との関係 を半径 $R$ をパラータとして示した.

まず，モデルAの結果についてみてみる.

図より, 淀み点 $R=0$ および淀夕点近傍の領域内 $(R$ $=0 \sim 2)$ の点 $R=1.25$ の場合の両者の $N u$ はほぼ同一 で，しかも時間てに無関係で高い值であり，また等熱流 束†5 または等温壁 ${ }^{5}$ の場合の $N u$ とほぼ同一である.

淀又点近傍の領域外の $R=2.5$ になると, $N u$ は $R$ $=0,1.25$ の $N u$ より低くなるが， $\tau$ の依存性はあまり 認められない. しかし，その $N u$ と等温壁および等熱流 束の $N u$ との間に差異が認められ，Nu は等温壁，モ デル A，等熱流束の順に大となつている.

†5 いずれも定常熱移動であるので，それらの $N u$ は時間に無関係に一 定である。また淀み点近傍の領域では両者の $N u$ は同一である2).
$R=5$ になると, $N u$ は $R=2.5$ のそれより低くな り，またての依存性が㴓められるよらになる。すなわ

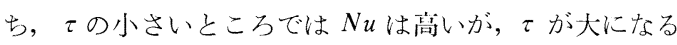
につれて小さくなり等温壁の $N u$ に漸近する†゙. さらに $\tau$ が大になると，逆に $N u$ は $\tau$ ともに高くなり等熱流 束の $N u$ に漸近する。 この傾向は $R \geq 10$ になると顕著 である。また図より $N u$ が極小になる時間はRが大にな るにつれて大となつている.

つぎにモデル Bの結果についてみてみる.

$R \leq 2.5(\tau \geq 0.01)$ ではモデル B の $N u$ は削述のモデル $\mathrm{A}$ の $N u$ と同一である.

$R=5$ では, モデル $\mathrm{B}$ の $N u$ は $\tau$ の小さいところで

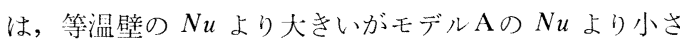
くまな時間の経過とともにモデルAの場合とはことな りての $N u$ は大となつて拉り, ある时间てでモデルAの $N u$ と一致する. この一致する時間は前述のモデルAの $N u$ が極小になる侍間とほぼ同じである。

以上のモデルBの $N u$ との関係は $R \geq 10$ の場合も 同様である。

以上のよらに, $\tau \geq 0.01$ では, $R \geq 5$ でかつての小さ いところでのみモデル $\mathrm{A}, \mathrm{B}$ の $N u$ がことなつている.

いま, 固体面上の流体の滞在時閒を概算するため, 速 度境界層内の平均流速を求め， それより $R=0 \sim R_{1}$ 間 の平均滞在時間 $\tau_{\mathrm{p}}$ を求めてみると, $R_{1}=5,10,20$, $30, R_{0}(37.5)$ のそれぞれにつき $\tau_{\mathrm{p}}=0.007, \quad 0.015$, $0.041 ， 0.11 ， 0.21$ として得られた. $R_{1}=5 \sim 30$ にお ける $\tau_{\mathrm{p}}$ は前述のモデル $\Lambda, \mathrm{B}$ の $N u$ が一致する時間 と同じオーダの值とみることができる (Fig. 4).

これより, モデル $\mathrm{A} の N u$ が著しい非定常性を示す時 間は初期の低温流体 $(\tau=0: T=0)$ が新しい流体で四 換される時間にほぼ対応すると考えられる。

(4) 固体内温度の経時変化に関する前報の尖験絬果 との比較

Fig. 2 4 と同一条件下の場命の冏体内温度: $T_{\mathrm{S}}$ の経 時変化に関するモデル A， B の計算伯と前報1)の実測 值とを Fig. 5 に示した.

Fig. 5 より， $\tau=0 \sim 310$ 閒の $T_{\mathrm{S}}$ はモデル A， Bに よつて差異はないとみなしらる。これは非定常対流伝熱 がごく初期 $(\tau<0.1)$ に限られているためである.

また $R=2.5$ の場合 (Fig. 5-(a)) の $T_{\mathrm{s}}$ の計算值 は $\tau$ の小いところでは尖測值より幾分低いが，夷測值 の傾向を十分あらわして抢り，またての大きいところで は両者はよく一致している.R=20の場合 (Fig. 5-(b))

$\dagger^{6}$ 前述の $R=2.5$ の場合も, $\tau<0.01$ でての小いところではN は 高く, てが大になるにつれて $N_{\mathrm{u}}$ は娍少する。 


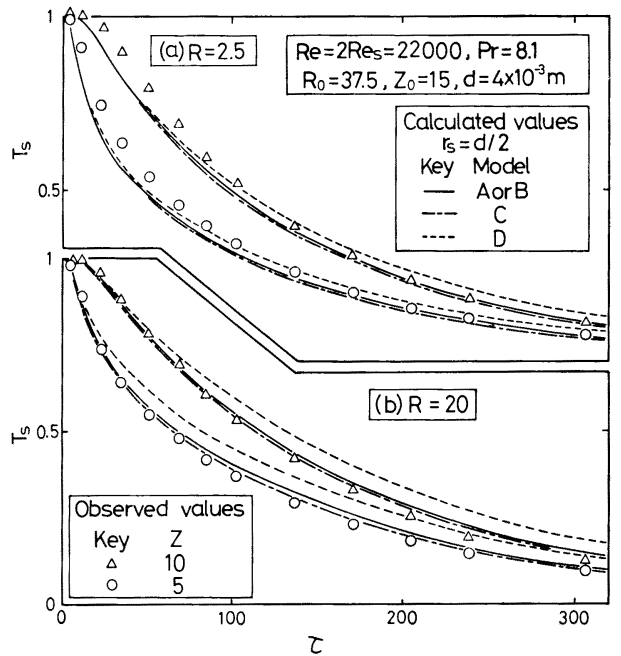

Fig. 5. Comparison between observed ${ }^{1)}$ and calculated temperatures in the disk under the same condition of Fig. 2-4.

には $\tau=0 \sim 310$ において部算优と失測值とはかなり良 く一致している.

\section{$3 \cdot 2$ モデルCおよびモデルの場合}

前報1)の条件下゙の熱移動現象は本来，モデルAあるい はモデルBなどにより考察されるべきことと思われる。 しかし，これらのモデルは複雑である，ところで, Fig. 4 より，てが大きいところではモデル $\mathrm{A}, \mathrm{B}$ の $N u$ は等 熱流束の $N u$ に近い，そこで，前述のごとく固体内温度 を等熱流束モデル（モデル G）で求めてみた。 また比較 のなめに等温壁モデル（モデルD）による固体内温度の 計算值も求めてみた。

\section{(1) 固体内温度分们}

Fig. 2 にモデルCおよびDの場合の固体内温度分布 の計算值を示した．図より， $\tau=0.1$ および $\tau=1$ では モデル $\mathrm{C}$ およ゙ $\mathrm{D} の$ 等温線の計算值には差異はなく，し かもそれらはモデル $\mathrm{A}, \mathrm{B}$ の計算值と一致している. しかし， $=10$ ではモデルDの等温線はモデル $\mathrm{A}, \mathrm{B}$ の それより高く，一方モデル $\mathrm{C} の$ 等温線はモデル $\mathrm{A}, \mathrm{B}$ の それより低くなる傾向が訫められる。ささらに時間が経過

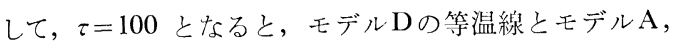
$\mathrm{B}$ の等温線との差異は大きくなるが，モデル $\mathrm{C}$ モデル $\mathrm{A} ， \mathrm{~B}$ の等温線の差異はとれほど大きくならない.

(2) 固体内温度の経時変化に関する前報の垁験結果 との比較

まず, Fig. 2 と同一条件下の場合の固体内温度 $T_{\mathrm{S}}$ の経時変化に関するモデル $\mathrm{C}, \mathrm{D}$ の計算值とモデル $\mathrm{A}$, B の計算值および前報 ${ }^{1)}$ の尖測值とを Fig. 5 に比較し
た.図より，モデル $\mathrm{C}$ の計算值はモデル $\mathrm{A} ， \mathrm{~B}$ のそれ より小さいが，しかしその差異はあまりなく，モデル $\mathrm{A} ， \mathrm{~B}$ と同様実測值とほぼ一致している. 一方モデルD の計算值はモデル $\mathrm{A} ， \mathrm{~B}$ のそれより大きく，その差異は

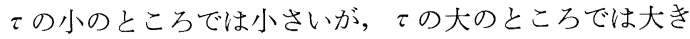
くなつており，またその計算值はてが大になるとともに 実測值より大になる傾向がある.

つぎに，Fig. 2 の条件とことなる場合について， モ デルCの計算值と前報1) の実測值とを Fig. 6〜10 に比 較した.

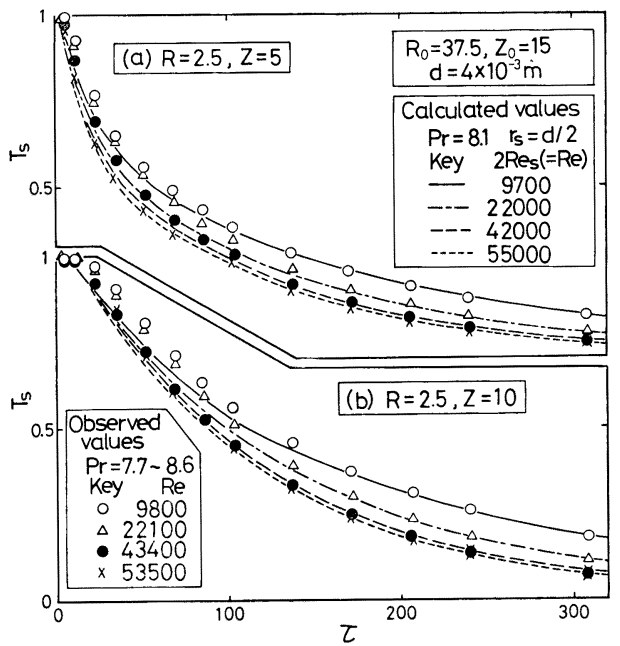

Fig. 6. Comparison between observed ${ }^{1}$ ) and calculated temperatures in the disk for different $R e$ $(R=2.5)$.

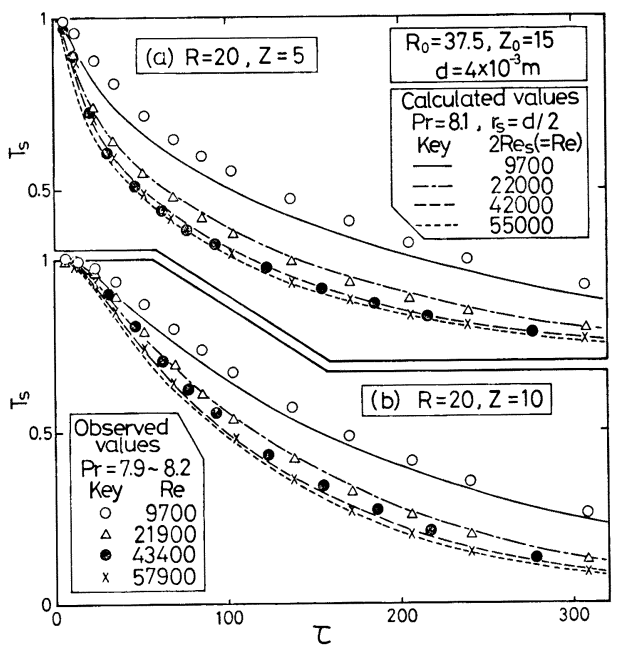

Fig. 7. Comparison ${ }^{\complement}$ between observed ${ }^{1)}$ and calculated temperatures in the disk for different $R e$ $(R=20)$. 


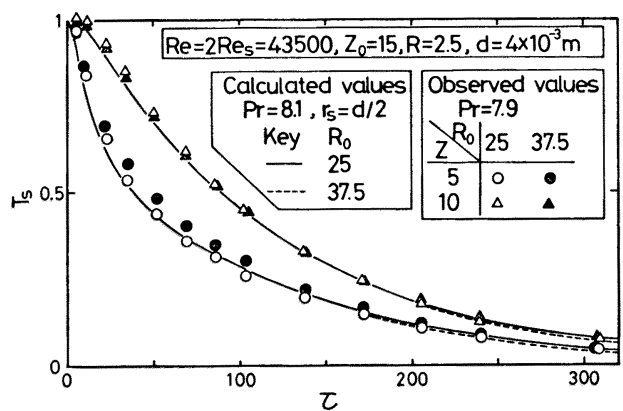

Fig. 8. Comparison between observed ${ }^{1)}$ and calculated temperatures in the disks with different radius.

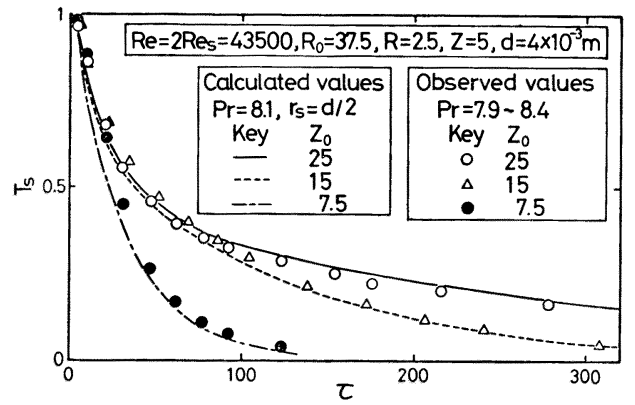

Fig. 9. Comparison between observed ${ }^{1}$ ) and calculated temperatures in the disks with different thickness.

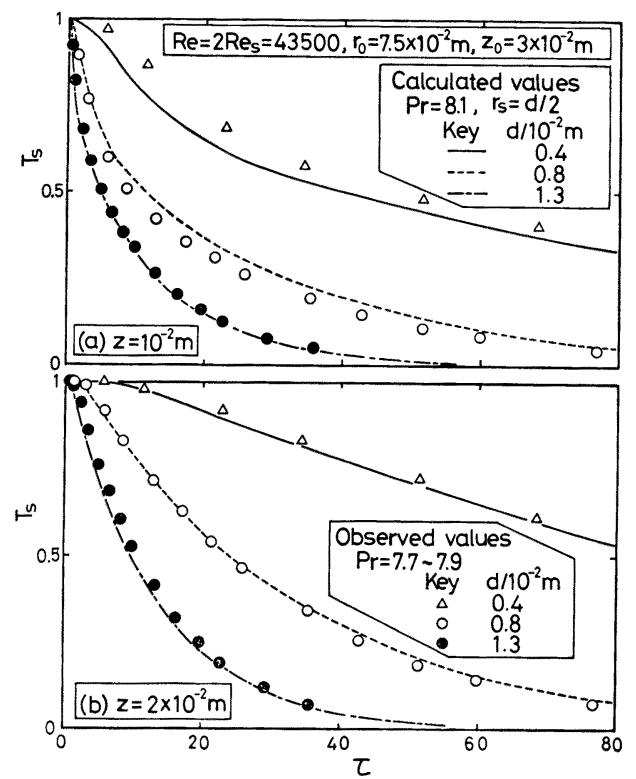

Fig. 10. Comparison between observed ${ }^{1)}$ and calculated temperatures in the disk for different diameter of nozzle.
これらの図より，計算值と実測值とがいずれの条件下 でもほぼ一致しているのがわかるげ.

以上，前報1)2）およひ本報の結果を要約するとつぎの よらになる。

前報1)で, 噴流水一固体円板間の対流伝熱と固体内熱 伝導の二つの過程からなる非定常熱移動現象を実験的に 検討した結果, 固体内温度の経時変化は Eq. (1)〜

(3)，(17) 拈よび Eq. (22) であらわされた.

$$
\begin{aligned}
& h_{\mathrm{r}} d=0.035 m\left(\frac{v_{\mathrm{s}} d}{\nu}\right)^{0.75} P_{\mathrm{r}} 0.4 \ldots \ldots \ldots \ldots \ldots \ldots \\
& \lambda=1(r=0 \sim d) ; m=(r / d)^{-0.5}\left(r=d \sim r_{0}\right)
\end{aligned}
$$

また前報 2 で，噴流水一固体円板間の定常対流伝熱を 検討し， $h_{\mathrm{r}}$ の数值解を得たが, Eq. (22) の実験式は 等熱流束の場合の数値解でほほぼ説明された。これより前 報1)の対流伝熱の条件は定常状態でかつ等熱流束の条件 と推察された.

本報では前報1)の熱移動現象が，非定常および擬定常 対流伝熱を仮定したモデルAおよび Bであらわされるこ とを示した.さらにこの現象が定常対流伝熱を仮定した 等熱流束モデル (モデル G) でも十分あらわされること も示した.このことは前報2)の推察と一致している.

\section{4. 結言}

前報1)で実験的に検尉した噴流水一固体山板 $(373 \mathrm{~K}$ 以下）間の非定常熱移動現象を非定常伝熱モデル（モデ ルA), 擬定常伝熱モデル（モデルB）, 等熱流束モデル (モデル $\mathrm{C})$, および等温壁モデル (モデルD) により理 論的に考察した.

得られた結果は以下のよらに要約される.

I 。モデルA打よびモデル Bの場合

(1) $R e_{\mathrm{S}}=11000, \quad \operatorname{Pr}=8.1, \quad R_{0}=37.5, Z_{0}=15$ の 場合の系内温度分布, 局所伝熱速度 $Q$ および局所又ッ七 ルト数 $N u$ の数值解はそれぞれ Fig. 2, Fig. 3 お上 び Fig. 4 で与えられる.

（2）両モデルの上記の数值解は冷却開始よりきわめ て短い時間の間ではことなるが，その後は一致する.こ の非定常対流伝熱から定常対流伝熱に移行する時間の才 一ダは境界層内の液の平均滞在時間のオーダとほぼ一致 する。

(3) 局所ヌッセルト数 $N u$ は時閒 $\tau$ が大になるにつ れて等熱流束の $N u$ に漸近する.

(4)上記条件下の固体内温度の経時変化に関する前! 報の実験結果はいずれのモデルでもあらわしらる（Fig. 5).

†7 Fig. 6 および $70 R e \leq 22000$ の条件では固体川板上に跳水が

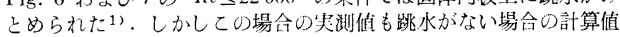
によつてほぼあらわきれている。 
II. モデル $\mathrm{C}$ およびモデルDの場命

(1) $R e_{\mathrm{S}}=11000, \operatorname{Pr}=8.1, R_{0}=37.5, Z_{0}=15$ の 場合の固体内温度分布の数值解は Fig. 2 で与えられ

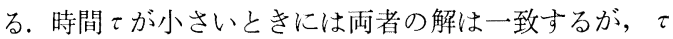
が大になるにつれて両者の解はことなつてくる，しか し，モデル $\mathrm{C}$ の解はモデル $\mathrm{A}, \mathrm{B}$ の解に近い.

(2) 固体内温度の経時変化に関する前報の実験結果 はモデルCであらわしらる（Fig. 5〜10).

（3）モデルGでは流体-円板間界面における熱の連 続条件は一般には成立しないので, その意味でモデル $\mathrm{C}$ はモデル A，B より厳密性を欠くが，前報の実験条件 下の熱移動に適用しらる簡単なモデルと考える.

\section{記号}

$c_{\mathrm{v}}:$ 水の比熱 $[\mathrm{J} / \mathrm{kg} \cdot \mathrm{K}]$

$d:$ ノズル内径 $[\mathrm{m}]$

$g$ : 重力加速度 $\left[\mathrm{m} / \mathrm{s}^{2}\right]$

$H:$ ノズル下端から試料円板表面までの距離 [m]

$h_{\mathrm{r}}$ : 局所伝熟係数 $\left[\mathrm{J} / \mathrm{m}^{2} \cdot \mathrm{s} \cdot \mathrm{K}\right]$

$N u: h_{\mathrm{r}} r_{\mathrm{s}} / \lambda$ (ヌッセルト数) [-]

$P e: R e_{\mathrm{S}} \cdot \operatorname{Pr}($ ペクレ数) [一]

$\operatorname{Pr}: c_{\mathrm{p}} \mu / \lambda$ (プラントル数) $[-]$

$Q$ ：無次元伝熱速㡺 (Eq. (20)-(a)) [-- ]

$q_{\mathrm{r}}:$ 熱流束 $\left[\mathrm{J} / \mathrm{m}^{2} \cdot \mathrm{s}\right]$

$R: r / r_{\mathrm{s}} \quad[-]$

$R_{0}: r_{0} / r_{\mathrm{s}}[-]$

$R_{\mathrm{j}}: r_{\mathrm{j}} / r_{\mathrm{S}} \quad[-]$

$R_{\mathrm{p}}: r_{\mathrm{p}} / r_{\mathrm{s}} \quad[-]$

$R e: d v_{0} / 2$ (レイノルズ数) $[-]$

$R e_{\mathrm{S}}: r_{\mathrm{s}} v_{0} / \nu$ (レイノルズ数) [-]

$r$ : 試料円板の中心から半径方向の距離 [m]

$r_{0}$ : 試料円板の半径 $[\mathrm{m}]$

$r_{\mathrm{j}}:$ 跳水点の半径 $[\mathrm{m}]$

$r_{\mathrm{p}}$ : 淀及点近傍の領域の半径 $(=d) \quad[\mathrm{m}]$

$r_{\mathrm{s}}$ : 衝突時噴流半径 $(=(d / 2)(1+\xi)-1 / 4 \quad[\mathrm{~m}]$
$T:\left(\theta-\theta_{\mathrm{W}}\right) /\left(\theta_{0}-\theta_{\mathrm{w}}\right) \quad[-]$

$T_{\mathrm{s}}:\left(\theta_{\mathrm{s}}-\theta_{\mathrm{w}}\right) /\left(\theta_{0}-\theta_{\mathrm{w}}\right) \quad[-]$

$t:$ 時間 $[\mathrm{s}]$

$U: u / v_{\mathrm{s}} \quad[-]$

$u$ : 半径方向の速度 $[\mathrm{m} / \mathrm{s}]$

$V: v / v_{\mathrm{s}} \quad[-]$

$v:$ 鉛直上方の速度 $[\mathrm{m} / \mathrm{s}]$

$v_{\mathrm{S}}$ : 衝突時噴流速度 $\left(=v_{0}(1+\xi)^{1 / 2}\right)[\mathrm{m} / \mathrm{s}]$

$v_{0}:$ ノズル内の水の沟流速 $[\mathrm{m} / \mathrm{s}]$

$Z: z / r_{\mathrm{s}}[-]$

$Z_{0}: z_{0} / r_{\mathrm{S}}[-]$

$z$ : 試料円板表而から鉛直下方への距離 [m]

$z_{0}$ : 試料円板の厚さ $[\mathrm{m})$

ギリシャ文字

$\alpha$ : 水の熱拡散摔 $\left[\mathrm{m}^{2} / \mathrm{s}\right]$

$\alpha_{\mathrm{R}}: \alpha / \alpha_{\mathrm{S}} \quad[-]$

$\alpha_{\mathrm{S}}$ : 試料円板の熱昖散率 $\left[\mathrm{m}^{2} / \mathrm{s}\right]$

$\Delta: \delta / r_{\mathrm{S}} \quad[-]$

$\delta:$ 境界層の厚さ $[\mathrm{m}]$

$\eta: z / \delta \quad[-]$

$\theta:$ 円板上の水の温度 [K]

$\theta_{0}$ : 試料円板の初期温度 [K]

$\theta_{\mathrm{s}}:$ 試料円板内の温度 [K]

$\theta_{\mathrm{w}}:$ ノメ゙ル内の水の温度 $[\mathrm{K}]$

$\lambda:$ 水の熱伝導度 $[\mathrm{J} / \mathrm{m} \cdot \mathrm{s} \cdot \mathrm{K}]$

$\lambda_{\mathrm{R}}: \lambda / \lambda_{\mathrm{S}} \quad[-]$

$\lambda_{\mathrm{s}}$ : 試料円板の熱伝導度 $[\mathrm{J} / \mathrm{m} \cdot \mathrm{s} \cdot \mathrm{K}]$

ע: 水の動粘度 $\left[\mathrm{m}^{2} / \mathrm{s}\right]$

$\xi: 2 g H / v_{0}^{2} \quad[-]$

$\tau: \alpha_{\mathrm{s}} t / r_{\mathrm{s}}^{2} \quad[-]$

\section{交献}

1) 菊池深，王井豊，谷口尚可，只木楨力，前田 四䬦：鉄と鋼，68 (1982)，p. 1932

2 ) 谷口尚司, 沢出勝実，料池 淙，只朴楨力：鉄と 鋼， 68 (1982), p. 1938

3 ) 山内二郎, 森口繁一, 一松 信: 数理科学シリ一 ズ 3 電子計算機のための数值計算法 II, (1967), p. 175 [培風館] 